5) Chlorpromazine and acetylcholine administration caused marked elevations in rabbit serum $\beta$ glucuronidase activity and the former produced increase in mouse kidney and muscle $\beta$-glucuronidase.

6) By glucose, alloxan, and insulin administration, rabbit serum $\beta$-glucuronidase activity fluctuated in parallel with the change of the blood suger level. The fluctuation was more sensitive and uniform than that of glucuronidogenic hormone administration.

7) From these results, though direct evidence to connect $\beta$-glucuronidase and glucose is lacking, glucose and related sugar metabolism may be one of the major components influencing the change of the $\beta$-glucuronidase activity, and glucuronidogenesis per se' is presumably not a major factor affecting the $\beta$-glucuronidase activity and elevation in the $\beta$-glucuronidase activity induced by hormone administration might be due to their action upon sugar metabolism.

It is undoubtedly premature to make any conclusion about $\beta$-glucuronidase action in vivo and at present, it would be proper to consider the main action of $\beta$-glucuronidase is a hydrolytic one, and in some cases it may be associated with the change of the sugar metabolism.

\title{
A New Method of Urinary ACTH Determination and its Clinical Application
}

\section{Hiroshi IBAYASHI, M.D. and Takuo FUJITA, M.D.}

Prof. Okinaka's Clinic, University of Tokyo School of Medicine (Director : Prof. Shigeo Okinaka)

A new benzoic acid absorption method and Sayers, Sayers, Woodbury's bioassay method was successfully used for quantitative determination of urinary ACTH in healthy subjects as well as patients with pituitary-adrenal disorders and under synthetic steroids therapy.

The recovery experiments showed about $76 \%$ by this method.

In 25 normal subjects the adrenal ascorbic acid depletion in hypophysectomized rat (AAD) caused by 26 extracts from $24 \mathrm{hr}$ urine was $51 \pm 6.5(\mathrm{M} \pm \mathrm{SE}) \mathrm{mg} /$ adrenal $100 \mathrm{~g}$, while ten samples corresponding to $12 \mathrm{hr}$ urine from 4 patients with Addison's disease gave highly significant increase of the AAD $(\mathrm{p}<0.001)$.

In both hypopituitarism (12 samples in 7 cases) and patients under steroid therapy (18 samples in 12 cases), significant decreases were noted (the former aver. $22 \pm 8.7 \mathrm{p}<0.02$, the latter aver. $15 \pm 7.9$ $\mathrm{p}<0.01)$.

In 5 cases of anorexia nervosa, 5 samples showed no significant difference both from normal or hypopituitarism.

In 10 samples from 6 cases of Cushing's syndrome with conclusive evidence of adrenal hyperplasia only 2 cases gave high ADD values, and one case with unilateral adenoma showed low AAD, followed by normal level postoperatively. Possible explanations for this are discussed. It was concluded that our new method of urinary ACTH determination was of great clinical usefulness. 


\title{
尿中 $\mathrm{ACTH}$ 新定量法及びその臨床知見
}

\author{
東京大学医学部冲中内科教室 \\ 井林博 \\ 藤田拓男
}

\section{I 緒}

言

下垂体副婜皮質機能検查法として尿中皮質久テロイドの測定と其に，血中ないし尿中 ACTH 定量は臨床 的に極めて有用であることは論を俟たない，下垂体 ACTH の化学的性状に関しては最近そのアるノ酸組成 に到る迄可成り詳細な知見がえられているが，なおその化学的定量法は確立されていない．著者の 1 人藤田 ${ }^{9}$ は1957年 Oxycellulose 吸着, Sayers，Sayers，Woodbury ${ }^{32)}$ (1948)の bioassay を用いた血中及び尿中 ACTH 定量法を考按発表した.

本法による尿中 ACTH 定量に関しては，本邦においてあ斎藤等 ${ }^{25}$ (1958)，勝木 ${ }^{17)}$ (1959)等の追試をみ るが，その後吾々自身の検討によれば回収率が必ずしも一定せず，又精度の点においてなお多くの検討の余 地が残されている。吾々は Lerner, Takahashi ${ }^{18)}$ (1959) が尿中メラニン細胞刺激ホルモン (MSH) の定量 に用いた安息香酸吸着法に準じ，之に若干の考按を加えた尿中 ACTH 抽出法により，同じくSayers 等の bioassay 法により検定する新らしい尿中 ACTH 定量法を試み，その臨床的有用性を認めると共に，現在 2 ， 3 の興味ある知見をえたのでことに発表し，諸家の御批判，御検討に俟ちたいと思う.

$$
\text { II 方法 }
$$

〔抽出法〕予じめ $6 \mathrm{~N}, \mathrm{HCl} 30 \mathrm{ml}$ を加えた蓄尿瓶に $24 \mathrm{hr}$ 尿を可及的冷暗所で蓄尿する，直ちに $40 \%$ $\mathrm{NaOH}$ を以て $\mathrm{pH} 5.2$ 2 5.5 調整する（水素イオン検定用紙 BSG 又は $\mathrm{pH}$ meter を用いる）.

次いで安息香酸飽和エタノールを尿 $100 \mathrm{ml}$ 当り $5 \mathrm{ml}$, 輸血針付き注射筒で急速に注入し, 攪找器を用いて 30 ～60分充分に攪拌して，ACTH を安息香酸に吸着ざせ。.ヌッエにより之を吸引濾過すると共に,安息香 酸飽和 Aq. dest. $100 \mathrm{ml}$ で 4 ～回充分に洗滌して尿色素, 尿酸等を除去し,安息香酸はヌッチエのまま $60^{\circ} \mathrm{C}$ 恒温器で略々乾固せしめる.

次いで安息香酸エキスをビーカーに移し，之に0.005N, HCl 1.0 2.0mlを加えて精製エーテル $\left(10 \% \mathrm{FeSO}_{4}\right.$ 1/5Vol. で 2 回洗淄） $100 \mathrm{ml}$ で 3 ～ 4 回洗つて安息香酸を溶解除去し，少量の水層エキスをうる. ての水首 エキスを試験管に移して，100 $\mathrm{C}$ 温浴中にて 5 分間加温して残存する少量エーテル 毒性物質を除去し，直ち に還沈して上清の約 $0.5 \mathrm{ml}$ 無色乃至淡黄褐色の ACTH Extract をうる.

検体は氷室に保存し速かに bioassay を行なう.

〔検定法〕検定には Sayers, Sayers, Woodbury（1948）の下垂体剔出白鼠副腎アスコルビン酸減少法によ る in vivo bioassay 法を用いた。 アスコルビン酸定量は Roe, Kuether 法 ${ }^{29)}$ (1944) によつた。即ち $25^{\circ} \mathrm{C}$ 恒 温飼育室において予め約 1 週間，オリエンタル固形食で餌育した体重 $130 \mathrm{~g}$ 前後の Wistar 系令白鼠を，傍呐 頭法により下垂体剔出を行ない，24hr 後検定に供した。検定には 1 検体に 1 匹宛用いたので，後述の如く 成績は各検体群間に統計処理を行なつた。

個々の症例についての定量值をうるためには 4，5 日間の尿を集め ACTH 抽出を行ない，之を $4 ， 5$ 匹 の白鼠を用いて bioassay する事が望ましい.

下垂体剔出白鼠はオーロパンソーダ嘛醉後，先ず左副腎を剔出したる後，左大伏在静脈から検体を 1 分間 で静注する． $1 \mathrm{hr}$ 後右副腎を剔出する．剔出した副腎は直ちに科量して（少くす $0.1 \mathrm{mg}$ の位迄測定） $4 \%$ 三塩 化酶酸 $10 \mathrm{ml}$ 及び少最の仯を入れた厚手スピッツに移し碍子棒で完全に挫碎する。次いで約 $0.3 \mathrm{~g}$ の活性炭末を 
第 1 表 USP ACTH 投与時の下垂体剔出白鼠AAD

\begin{tabular}{|c|c|c|c|}
\hline$\underset{\mathrm{mu}}{\mathrm{ACTH}}$ & $\begin{array}{c}\text { No. } \\
\text { of } \\
\text { Explt. }\end{array}$ & $\begin{array}{c}\text { hypophysectomized rat AAD } \\
\text { (mg/Adrenal } 100 \mathrm{~g})\end{array}$ & $\mathrm{M} \pm \mathrm{SE}$ \\
\hline 0 & 7 & $-19,13,21,-10,-7,0,-10$ & $0 \pm 5.3$ \\
\hline 0.25 & 6 & $38,90,16,58,25,36$ & $44 \pm 7.6$ \\
\hline 0.5 & 9 & $90,89,77,61,30,41,60,43,109$ & $66 \pm 8.7$ \\
\hline 1.0 & 6 & $118,88,112,91,68,84$ & $93 \pm 7.6$ \\
\hline 2.0 & 13 & 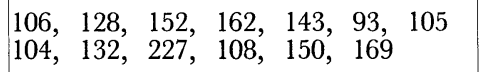 & 136 \\
\hline
\end{tabular}

加光て少くむ 1 分間硝子棒で攪汼 したる後濾過する。濾液 $4.0 \mathrm{ml}$ ⿸ とりチオ尿素液 1 ～2 滴 $(10 \mathrm{~g}$ の オ尿素を50\%エタノール溶液 100 $\mathrm{ml}$ に溶解したあの) と 2,4 dinitrophenylhydrazine 溶液 $1 \mathrm{ml}(2 \mathrm{~g}$ を $9 \mathrm{~N} . \mathrm{H}_{2} \mathrm{SO}_{4} 100 \mathrm{ml}$ 亿溶解)を加 光, $60^{\circ} \mathrm{C}, 1 \mathrm{hr}$.温浴後, 水水中に 保ちながら $85 \% \mathrm{H}_{2} \mathrm{SO}_{4} 5 \mathrm{ml}$ を加 える。室温で30分間放置 後 Uni versal Coleman 光電比色計で $540 \mathrm{~m} \mu$ の吸光度を求 わる. 対照には検体濾液 $4 \mathrm{ml}$ の代りに $4 \%$ 三塩化酢 酸 $4 \mathrm{ml}$ を用いて作製すると共に，アスコルビン酸 標準液と比色して溶液中のアスコルビン酸含有量を 求める.副腎100g中のアスコルビン酸量を算出して, 左副腎100g中のアスコルビン酸含量と右副㹂のそれ との差 (Adrenal ascorbic acid depletion, AAD L-R）が ACTH に対する副腎反応を定量的に示す。 予備実験によれば下垂体剔出白鼠の左右副㱟アスコ ルビン酸量は左右同時又は $1 \mathrm{hr}$ 間隔で剔出した際も AAD $20 \mathrm{mg}<$ ととはなく，10mg＜のととは稀で ある。なお検定時にはその都度同時に USP 標準 ACTHによるAADを求めることが望ましい，USP Standard ACTH 投与時の AAD は第 1 表, 第 1 図 の如くであり，投与 $\mathrm{ACTH}$ 量の対数と $\mathrm{AAD}$ が 比例し， $\mathrm{y}=116 \mathrm{x}-13.8, \lambda=0.21$ である. 又, $2 \mathrm{mu}$, 0.5mu そおける Pugsley 検定による本法の 回収率 は第 2 表の示す如く75７8\%である。

なお尿中 ACTH と併世定量せる尿中 Total 17OHCS，17KS は夫々 Sigma 製細菌性 $\beta$-glucuronidase による Glenn, Nelson 変法, Drekter 変法によ つた.

第 2 表 USP ACTH 回収試験(Pugsley 検定)

\begin{tabular}{|c|c|c|c|c|}
\hline No. & ACTH & $\begin{array}{l}\text { hypophysectomized rat } \\
\text { AAD }\end{array}$ & $\mathrm{M} \pm \mathrm{SE}$ & 回収率 \\
\hline I & $\begin{array}{r}2 \mathrm{mu} \\
0.5 \mathrm{mu}\end{array}$ & $\begin{array}{l}87,102,112,193,114 \\
24,51,81,61,75\end{array}$ & $\begin{array}{r}122 \pm 18.5 \\
58 \pm 10.1\end{array}$ & $\begin{array}{l}77.8 \% \\
(96.0 \sim 63.1)\end{array}$ \\
\hline II & $\begin{array}{r}2 \mathrm{mu} \\
0.5 \mathrm{mu}\end{array}$ & $\begin{array}{l}101,162,81,122,79 \\
87,43,67,84\end{array}$ & $\begin{array}{r}109_{ \pm} 15.4 \\
70_{ \pm} 10.1\end{array}$ & $\begin{array}{l}75.1 \% \\
(94.0 \sim 60.0)\end{array}$ \\
\hline
\end{tabular}

III 成 績

先ず正常人 25 例 (26検体) の測 定成績は第 3 表の如く $24 \mathrm{hr}$ 永中 $\mathrm{ACTH}(\mathrm{AAD})$ は平均 $51 \pm 6.5 \mathrm{mg} /$ Adr. $100 \mathrm{~g}$ で，尿中 $17 \mathrm{OHCS}, 17 \mathrm{KS}$ は夫々 $2.8 \pm 0.16 \mathrm{mg} / \mathrm{day}, 8.9 \pm$

$0.50 \mathrm{mg} / \mathrm{day}$ であつた. 次に Addison 病 4 例について加療前の $12 \mathrm{hr}$ 尿10検体の ACTH(AAD) は平均 $136 \pm$ 14.2 で (17OHCS $0.3 \pm 0.03 \mathrm{mg} / \mathrm{day}, 17 \mathrm{KS} 4.0 \pm 0.92 \mathrm{mg} / \mathrm{day})$ 第 3 表, 第 4 表の如く有意の著增 $(\mathrm{P}<0.001)$ を示したが，興味ある事はNo. 3，No. 4 の 2 例では Hydrocortisone 20〜40 mg/day の加療後 1 週〜 1 力 月後に臨床的改善と相俟つて正常化の傾向をみた事である. 
第3 表 尿中 ACTH 这びに17OHCS，17KS测定成䋶

I. 正常人

\begin{tabular}{|c|c|c|c|c|c|c|}
\hline No. & Name & Sex & Age & $\begin{array}{c}\text { ACTH } \\
\text { (AAD mg/Adr. 100g) } \\
\end{array}$ & $\begin{array}{l}\text { 17OHCS } \\
(\mathrm{mg} / \text { day })\end{array}$ & $\begin{array}{c}17 \mathrm{KS} \\
\text { (mg/day) }\end{array}$ \\
\hline 1 & F. I . & 우 & 15 & 30 & 1.9 & 6.5 \\
\hline 2 & T. I. & $\hat{o}$ & 16 & 57 & 2.7 & 10.4 \\
\hline 3 & Y.O. & 우 & 19 & 63 & 2.9 & 7.8 \\
\hline 4 & S.O. & 우 & 20 & 80 & 2.8 & 8.5 \\
\hline 5 & N. I . & $\hat{\delta}$ & 21 & 72 & 3.2 & 14.0 \\
\hline 6 & F.S. & 今̂ & 21 & 70 & 2.1 & 7.3 \\
\hline 7 & Y.Y. & 우 & 22 & 78 & 4.3 & 6.5 \\
\hline 8 & K. T. & 우 & 22 & -27 & 2.7 & 7.3 \\
\hline 9 & H. I. & 우 & 25 & 67 & 2.0 & 7.0 \\
\hline 10 & N.N. & 今ิ & 25 & 73 & 4.5 & 9.0 \\
\hline 11 & A.N. & 우 & 27 & 9 & 4.5 & 11.0 \\
\hline 12 & K.O. & 令 & 28 & 52 & 1.8 & 9.2 \\
\hline 13 & S.T. & 우 & 29 & 82 & 2.0 & 4.3 \\
\hline 14 & Y.O. & 우 & 30 & 45 & 4.0 & 7.0 \\
\hline 15 & T. I . & 우 & 31 & 38 & 3.2 & 9.8 \\
\hline 16 & S.H. & $\hat{\delta}$ & 31 & 51 & 2.4 & 7.4 \\
\hline 17 & Y.K. & 우 & 34 & 63 & 2.3 & 9.0 \\
\hline 18 & H.K. & $\hat{\jmath}$ & 35 & 70 & 3.0 & 7.6 \\
\hline 19 & S.T. & 우 & 35 & 58 & 3.5 & 8.8 \\
\hline 20 & T.Y. & 占 & 36 & 94 & 2.6 & 12.4 \\
\hline 21 & S.F. & 우 & 45 & 6 & 2.5 & 10.8 \\
\hline 22 & K.N. & $\hat{\beta}$ & 46 & 55 & 1.8 & 8.6 \\
\hline 23 & K.N. & 令 & 46 & 7 & 2.1 & 8.4 \\
\hline 24 & Y.N. & 㑒 & 49 & -29 & 3.0 & 15.0 \\
\hline 25 & S.S. & 우 & 54 & 66 & 2.3 & 5.0 \\
\hline 26 & T. T. & $\hat{\delta}$ & 70 & 90 & 2.5 & 12.3 \\
\hline \multicolumn{4}{|c|}{$\mathrm{M}_{ \pm} \mathrm{SE}$} & $51 \pm 6.5$ & $2.8 \pm 0.16$ & $8.9 \pm 0.50$ \\
\hline
\end{tabular}

II. Addison 病

\begin{tabular}{|c|c|c|c|c|c|c|}
\hline No. & Name & Sex & Age & $\begin{array}{l}\mathrm{ACTH}(\mathrm{AAD}) \\
12 \mathrm{hr} \text { 尿 }\end{array}$ & $\begin{array}{l}17 \mathrm{OHCS} \\
\text { (mg/day) }\end{array}$ & $\begin{array}{c}17 \mathrm{KS} \\
\text { (mg/day) }\end{array}$ \\
\hline 1 & N.F. & 우 & 35 & 105 & 0.4 & 4.5 \\
\hline 2 & S.H. & 令 & 37 & $\begin{array}{l}236 \\
190\end{array}$ & 0.3 & 0.5 \\
\hline 3 & K.N. & 令 & 39 & $\begin{array}{r}93 \\
123\end{array}$ & 0.3 & 5.2 \\
\hline & & & & 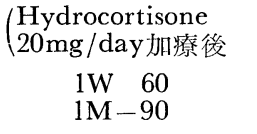 & & \\
\hline 4 & H.K. & 令 & 42 & $\begin{array}{l}150 \\
107 \\
127 \\
103 \\
131\end{array}$ & $\begin{array}{l}0.2 \\
0.3\end{array}$ & $\begin{array}{l}4.3 \\
5.7\end{array}$ \\
\hline
\end{tabular}




\begin{tabular}{c|c|c|c|c}
$\mid$ & & $\left.\begin{array}{c}\text { Hydrocortisone } \\
20,40 \mathrm{mg} / \text { day 加療後 }\end{array}\right)$ & & \\
$2 \mathrm{~W}-31$ & $136 \pm 14.2$ & $0.3 \pm 0.03$ & $4.0 \pm 0.92$ \\
\hline $\mathrm{M} \pm \mathrm{S} \mathrm{E}$ & 1 & & \\
\hline
\end{tabular}

Panhypopituitarism

\begin{tabular}{|c|c|c|c|c|c|c|c|}
\hline No. & Name & Sex & Age & Diagnosis & $\begin{array}{l}\text { AGTH } \\
\text { (AAD) } \\
\end{array}$ & 17OHCS & $17 \mathrm{KS}$ \\
\hline 1 & $\mathrm{~K} . \mathrm{T}$. & 우 & 9 & Lorain, Levy症候群 & 1 & 0.6 & 1.3 \\
\hline 2 & 11 & "1 & & 11 & 49 & 1.6 & 1.1 \\
\hline 3 & 11 & $!$ & & $\prime \prime$ & 13 & 0.4 & 1.3 \\
\hline 4 & " & "I & & $\prime \prime$ & 7 & & \\
\hline 5 & Y.K. & 우 & 29 & Simmonds 病 & 33 & 0 & 3.0 \\
\hline 6 & $" 1$ & "I & & "1 & 22 & 0.8 & 4.1 \\
\hline 7 & $\prime \prime$ & 11 & & "I & 23 & 1.4 & 2.2 \\
\hline 8 & $\mathrm{~J} \cdot \mathrm{U}$. & 우 & 34 & Sheehan 症候群 & 14 & 0.4 & 2.0 \\
\hline 9 & K. T. & 令 & 36 & Simmonds 病 & 31 & 0.7 & 5.4 \\
\hline 10 & T. I . & 우 & 37 & Sheehan 症候群 & -16 & 0.8 & 2.8 \\
\hline 11 & K.M. & 우 & 37 & "I & 100 & 0.5 & 3.4 \\
\hline 12 & T. I. & $\hat{\delta}$ & 39 & Simmonds 病 & -4 & 0.4 & 3.7 \\
\hline & & & & $\mathrm{M} \pm \mathrm{SE}$ & $22 \pm 8.7$ & $0.6 \pm 0.14$ & $2.7 \pm 0.40$ \\
\hline
\end{tabular}

IV Anorexia nervosa

\begin{tabular}{|c|c|c|c|c|c|c|}
\hline No. & Name & Sex & Age & AGTH & 17 OHCS & $17 \mathrm{KS}$ \\
\hline 1 & Y.S. & 우 & 15 & 54 & 0.7 & 3.2 \\
\hline 2 & A.N. & 우 & 16 & 25 & 1.5 & 5.0 \\
\hline 3 & S.O. & 우 & 21 & 37 & 1.0 & 6.5 \\
\hline 4 & S.Y. & 우 & 27 & 107 & 0.9 & 4.8 \\
\hline 5 & K. I . & 우 & 28 & -20 & 2.8 & 5.8 \\
\hline \multicolumn{4}{|c|}{$\mathrm{M} \pm \mathrm{SE}$} & $41 \pm 20.2$ & $1.3 \pm 0.38$ & $5.0 \pm 0.55$ \\
\hline
\end{tabular}

V 合成皮質ステロイド剂加療患者

\begin{tabular}{|c|c|c|c|c|c|c|c|c|}
\hline No. & Name & Sex & Age & Diagnosis & $\mid \begin{array}{c}\text { Steroid 剂* } \\
\mid \text { 投与総量mg～投与日 days }\end{array}$ & ACTH & 17OHCS & $17 \mathrm{KS}$ \\
\hline 1 & F.H. & 우 & 15 & 無 & D. $56 \sim 14$ & -5 & 0 & 10.5 \\
\hline 2 & M.S. & 우 & 19 & 結 & $\operatorname{Pr} .140 \sim 7$ & -21 & 1.0 & 4.4 \\
\hline 3 & F.K. & $\hat{\delta}$ & 21 & " & $\operatorname{Pr} .280 \sim 14$ & 25 & 0.8 & 3.7 \\
\hline 4 & H.O. & $\hat{\delta}$ & 25 & 滲出性肋膜炎 & $\operatorname{Pr} .140 \sim 7$ & 32 & 0.3 & 5.6 \\
\hline 5 & A.N. & $\hat{\delta}$ & 25 & "l & D. $21 \sim 7$ & 40 & 0.9 & 3.5 \\
\hline 6 & $\mathrm{~J} \cdot \mathrm{I}$. & $\hat{\delta}$ & 26 & 友 & M.112 7 & -35 & 1.5 & 3.2 \\
\hline 7 & K.O. & 우 & 31 & エリテマトーデJ & M.336 21 & 36 & 2.8 & 3.2 \\
\hline 8 & K.O. & 11 & 11 & $\prime \prime$ & $M+D .28 \sim 7$ & -4 & 1.1 & 3.5 \\
\hline 9 & "1 & $" 1$ & 11 & "I & $M+D .56 \sim 14$ & 30 & 1.2 & 3.0 \\
\hline 10 & 11 & $" 1$ & 11 & "1 & $M+D .84 \sim 21$ & 80 & 2.9 & 3.5 \\
\hline
\end{tabular}




\begin{tabular}{|c|c|c|c|c|c|c|c|c|}
\hline 11 & "I & $\prime \prime$ & "1 & "I & $\mathrm{M}+\mathrm{D} .112 \sim 28$ & 57 & 1.8 & 0.5 \\
\hline 12 & "I & 11 & $" /$ & "1 & $\mathrm{M}+\mathrm{D} .140 \sim 35$ & 66 & 1.5 & 0.9 \\
\hline 13 & $\mathrm{~K} . \mathrm{O}$ & $\hat{o}$ & 32 & 蝴 蛛 膜 炎 & $\operatorname{Pr} .700 \sim 35$ & -12 & 0.5 & 6.2 \\
\hline 14 & M.M. & 우 & 35 & 脊 髄 腫 痬 & D. $63 \sim 21$ & 15 & 0.8 & 2.2 \\
\hline 15 & $\mathrm{~S} . \mathrm{T}$ & $\hat{o}$ & 42 & 多発性神経 炎 & D.84一28 後30日 & -26 & 0.4 & 1.8 \\
\hline 16 & S.Y. & 우 & 59 & 春 䯣 腫 痬 & D. $21 \sim 7$ & -26 & 1.0 & 7.9 \\
\hline 17 & S.Y. & 11 & 11 & $\prime \prime$ & D. $118 \sim 14$ & 3 & 1.2 & 4.6 \\
\hline 18 & $\mathrm{~T} . \mathrm{T}$. & $\hat{\delta}$ & 70 & 細胆管性 肝 炎 & D.118～54 後 14日 & 18 & 1.7 & 6.8 \\
\hline & & & & & $\mathrm{M} \pm \mathrm{SE}$ & $15 \pm 7.9$ & $1.1 \pm 0.18$ & $3.6 \pm 0.48$ \\
\hline
\end{tabular}

* D. : Dexamethasone Pr. : Prednisolone M. : Medrol

VI Cushing 症候群 $* 12 \mathrm{hr}$ 尿中

\begin{tabular}{|c|c|c|c|c|c|c|c|}
\hline No. & Name & Sex & Age & 副 腎 病 変 & ACTH & $\begin{array}{c}\text { 17OHGS } \\
\text { (mg/day) }\end{array}$ & $\begin{array}{c}17 \mathrm{KS} \\
(\mathrm{mg} / \text { day })\end{array}$ \\
\hline 1 & H.S. & 今 & 11 & hyperplasia & $\begin{array}{ll}* & 101 \\
* & 128\end{array}$ & 7.5 & 14.2 \\
\hline 2 & S.M. & 今 & 12 & hyperplasia & 45 & 5.8 & 9.1 \\
\hline 3 & S.E. & 우 & 25 & $\begin{array}{l}\text { nodular } \\
\text { hyperplasia } \\
\qquad(1 \text { 側 adren }\end{array}$ & 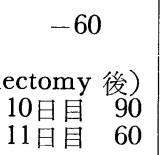 & $\begin{array}{l}0.5 \\
3.9\end{array}$ & $\begin{array}{l}4.5 \\
6.1\end{array}$ \\
\hline 4 & K. Y. & 우 & 26 & hyperplasia & $\begin{array}{l}* 37 \\
* 6\end{array}$ & 25.0 & 3.9 \\
\hline 5 & $\mathrm{~T} . \mathrm{K}$. & 우 & 29 & hyperplasia? & $\begin{array}{r}-16 \\
15\end{array}$ & $\begin{array}{l}12.6 \\
12.5\end{array}$ & $\begin{array}{l}14.2 \\
13.0\end{array}$ \\
\hline 6 & F.M. & 우 & 33 & hyperplasia & $\begin{array}{l}* 125 \\
* 121\end{array}$ & 7.0 & 7.6 \\
\hline 7 & Y.H. & 우 & 28 & 1. Adenoma & $\begin{array}{c}80 \\
-70 \\
-67 \\
(\mathrm{~A} \mathrm{~V} \cdot-28) \\
\\
\text { 10日 } \quad 22 \\
20 \text { 日 } \\
93 \\
90 \text { 日 }-22\end{array}$ & $\begin{array}{l}3.5 \\
5.8 \\
\\
0.3 \\
0.8 \\
4.2\end{array}$ & $\begin{array}{l}12.6 \\
12.7\end{array}$ \\
\hline
\end{tabular}

VII 其の他の内分泌疾患及び肥㭌症

\begin{tabular}{|c|c|c|c|c|c|c|c|}
\hline No. & Name & Sex & Age & Diagnosis & AGTH & $17 \mathrm{OHCS}$ & $17 \mathrm{KS}$ \\
\hline 1 & K. S . & 昘 & 25 & Acromegaly & 32 & 4.0 & 11.9 \\
\hline 2 & $\begin{array}{l}\text { M.H. } \\
\text { M.H. }\end{array}$ & $\begin{array}{l}\text { 全 } \\
\text { 今 }\end{array}$ & 30 & "1" & $\begin{array}{l}77 \\
70\end{array}$ & 0.8 & 5.1 \\
\hline 3 & H. I. & 우 & 32 & $" 1+\mathrm{D} \cdot \mathrm{M}$. & 113 & 2.1 & 13.7 \\
\hline 4 & Y.M. & $\hat{\delta}$ & 29 & Basedow & $\begin{array}{r}-9 \\
48 \\
18\end{array}$ & 4.7 & 9.0 \\
\hline 5 & Y.N. & $\hat{\delta}$ & 26 & $\begin{array}{l}\text { Myxödem } \\
\text { (加療後) }\end{array}$ & $\begin{array}{r}1 \\
70 \\
63\end{array}$ & $\begin{array}{l}1.7 \\
2.4\end{array}$ & $\begin{array}{l}5.7 \\
5.4\end{array}$ \\
\hline
\end{tabular}




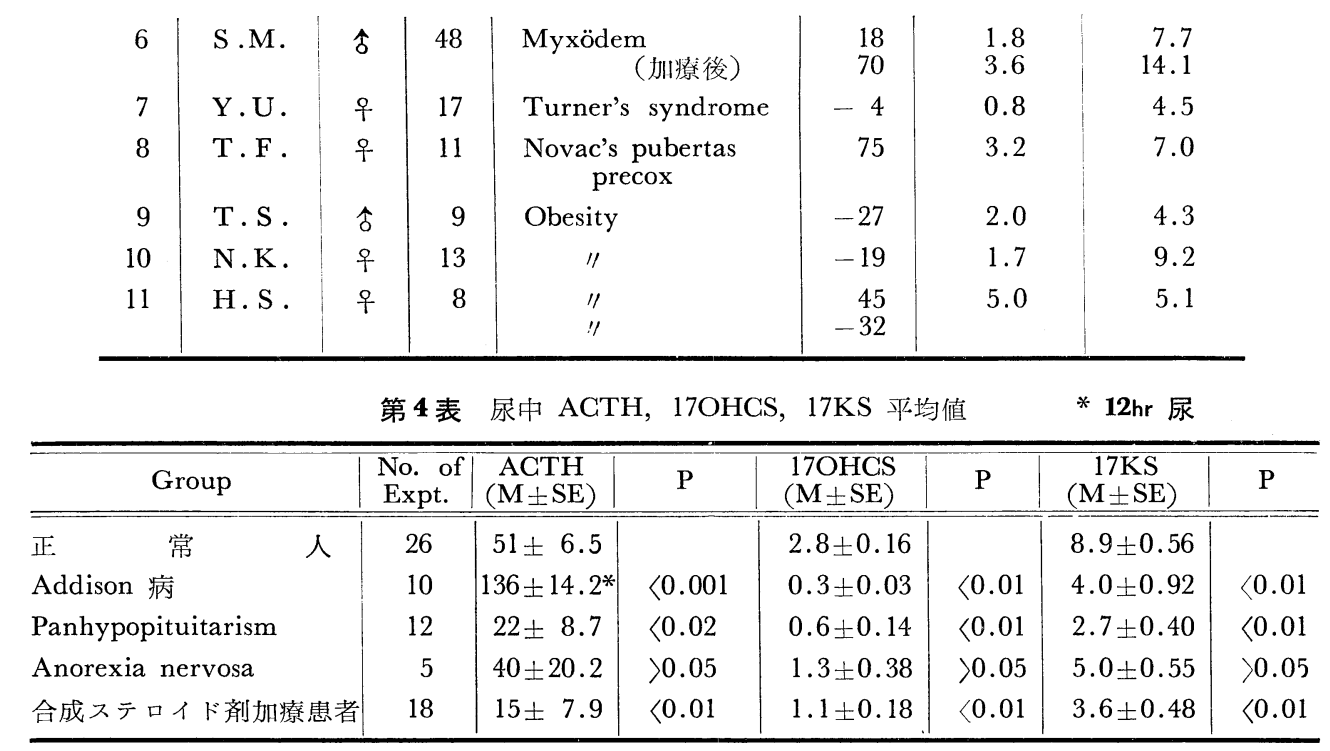

Lorain, Levy 症候群, Simmonds 病, Sheehan 症候群等の Hypopituitarism の 7 例（12検体）の尿中 ACTH は,之に反して平均 $22 \pm 8.7$ (17OHCS $0.6 \pm 0.14 \mathrm{mg} / \mathrm{day}, 17 \mathrm{KS} 2.7 \pm 0.40 \mathrm{mg} / \mathrm{day}$ )で正常人に比べ有 意の著減を認めた $(\mathrm{P}<0.02)$. しかしながら臨床的に本症との鑑別診断が問題となる Anorexia nervosa 5 例， 5 検体の $\mathrm{ACTH}(\mathrm{AAD}$ ) 平均 $40 \pm 20.2$ (17OHCS $1.3 \pm 0.38 \mathrm{mg} / \mathrm{day}, 17 \mathrm{KS} 5.0 \pm 0.55 \mathrm{mg} / \mathrm{day}$ ) との間 には有意差は見出しえなかつた。

又，Anorexia nervosa と正常人群との間にも特に有意の差異は認め難い.

次に種々合成皮質ステロイド剂加療患者12例（18検体の尿中 ACTH, 17OHCS, 17KS は夫々 $15 \pm 7.9,1.1$ $\pm 0.18 \mathrm{mg} / \mathrm{day}, 3.6 \pm 0.48 \mathrm{mg} / \mathrm{day}$ で正常人に比べ共に有意の著減を示し $(\mathrm{P}<0.01)$, 所謂 iatrogenic adrenal insufficiency の本態は諸家の推定する如く, 内因性の ACTH 分泌合成の抑制が一義的であると理解 される.

Cushing 症候群に関しては，その副腎病変が hyperplasia か又は adenoma, cancer であるか否かの鑑別 診断上, 血中乃至尿中 ACTH 定量の意義が重視されている. 吾々は手術によりその皮質病变を確認せる 6 例 及び ACTH Z Test, Dexamethasone Test 成績から hyperplasia と推定し, 最近正常姃娠分婏をみた No. 5 の 1 例計 7 例において, 尿中 ACTH を検討せる成績は第 3 表の如くである. 即ち hyperplasia (nodular hyperplasia の No. 3 を含む） 6 例中，No. 1，No. 6 の 2 例においては子期の如く増加を認めたが， No. $2,3,4,5$ の 4 例では有意の増加を示さなかつた事が注目される. 左側皮質腺腫の No. 7 では術前 ACTH は減少をみとめ, 術後正常化の傾向を示した，従つて本症候群における皮質病変の鑑別診断上，尿中ACTH 定量の意義は，更に今後の検討に残された興味ある問題之考える.

その他の諸種内分泌疾患についての測定成績は第 3 表の如くであるが，何れあ少数例のため結論はさける が，原発性粘液水腫 2 例で加療後尿中 ACTH の低值が回復の傾问をみた点は眮味深く，今後症例を重ねて 検討の予定である。

$$
\text { IV 考按 }
$$

尿中 AGTH 定量法に関しては1936年 De Boissezon ${ }^{8)}$ の報告以降諸家の成䋶をみるが，その抽洁法及び梌 定法を一括表示すると第 5 表の如くである。しかし藤田 ${ }^{7}$ (1957) の Oxycellulose, 下垂体剔出白鼠副腎アス コルビン酸減少法による正常人 10 例 23 検体の測定值平均 約 $0.25 \mathrm{mu}$ と報ずる成績以前の報告はその抽活㳂 
第 5 表 尿中 ACTH 定量成績（文献例）

\begin{tabular}{|c|c|c|c|c|c|c|}
\hline & References & Source & Preparation & $\begin{array}{l}\text { Total Vol. } \\
\text { per animal } \\
(\mathrm{ml})\end{array}$ & Assay method & $\begin{array}{l}\text { ACTH } \\
\text { Activity }\end{array}$ \\
\hline (1) & $\begin{array}{r}\left.\text { DeBoissezon }^{8}\right) \\
(1936)\end{array}$ & 妊婦 & 尿 & 16 & 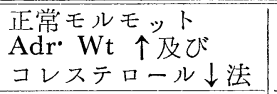 & $(+)$ \\
\hline (2) & $\begin{array}{c}\text { Paschkis, Rakoff, } \\
\text { a. Cantarow }{ }^{25)} \\
(1942)\end{array}$ & norm. & $\begin{array}{l}70 \sim 86 \% \\
\mathrm{EtOH} \text { 沈澱 }\end{array}$ & & $\left.\begin{array}{l}\text { 幼若雞 } \\
\text { 幼若rat }\end{array}\right\}$ Adr. Wt $\uparrow$ 法 & $(+)$ \\
\hline (3) & $\begin{array}{c}\text { Jones a. Bucher }{ }^{16)} \\
(1943)\end{array}$ & norm. & 硫安分劃 沈澱 & $200 \sim$ & $\begin{array}{l}\text { hypophysex } \\
\text { rat Adr. Wt. } \uparrow \text { 法 }\end{array}$ & $(-)$ \\
\hline (4) & $\begin{array}{c}\text { Blumenthal }{ }^{3)} \\
(1945)\end{array}$ & $\begin{array}{l}\text { norm. } \\
\text { 妊 婦 }\end{array}$ & 尿 & $4 \sim 16$ & $\begin{array}{l}\text { 正常モルモット } \\
\text { Adr. Mitosis } \uparrow \text { 法 }\end{array}$ & $(+)$ \\
\hline (5) & $\begin{array}{l}\text { Reiss, Peglar, } \\
\left.\text { a. Golla }{ }^{28}\right) \\
(1946)\end{array}$ & 妊 婦 & $\begin{array}{l}\text { 1)原尿 } \\
\text { 2)安息香酸吸着 } \\
\text { 3) ピクリン酸沈澱 }\end{array}$ & 25 & $\begin{array}{l}\text { hypophysex. } \\
\text { rat sudanophobe } \\
\text { zone 消失法 }\end{array}$ & $\begin{array}{l}(-) \\
(-) \\
(+)\end{array}$ \\
\hline (6) & $\begin{array}{c}\left.\text { Williamson }{ }^{37}\right) \\
(1946)\end{array}$ & $\underset{\substack{+ \\
\text { norm. }}}{\operatorname{nor}}$ & $\begin{array}{l}\text { 1)原尿 } \\
\text { 2)透析 } \\
\text { 3)透析後アセトン } \\
\text { 沈澱 } \\
\text { 4)透析後, 蒸溜, } \\
\text { アセトン沈涉 }\end{array}$ & $\begin{array}{c}4 \\
4 \\
120 \sim 460 \\
30\end{array}$ & $\begin{array}{l}\text { norm. rat } \\
\text { Adr. Wt. } \uparrow \text { 法 } \\
\text { hypophysex. } \\
\text { rat AAD 法 }\end{array}$ & $(+)$ \\
\hline ( 7 ) & $\begin{array}{c}\text { Cooke, Graetzer, } \\
\text { a. Reiss }{ }^{7)}(1949)\end{array}$ & norm. & $\begin{array}{c}\text { Permutit } \\
\text { 吸着 }\end{array}$ & 250 & $\begin{array}{l}\text { hypophysex. } \\
\text { rat AAD 法 }\end{array}$ & $(+)$ \\
\hline (8) & $\begin{array}{l}\text { Locks, Albert, } \\
\text { a. Kepler }{ }^{19)} \\
(1949)\end{array}$ & $\begin{array}{l}\text { norm. } \\
\text { Addison } \\
\text { Cushing }\end{array}$ & $\begin{array}{l}\text { アセトン沈澱 } \\
\text { 透析法 }\end{array}$ & $\begin{array}{l}24 \mathrm{hr} \text { 尿中 } \\
10 \sim 23 \% \text { Vol. }\end{array}$ & & $(-)$ \\
\hline (9) & $\begin{array}{l}\text { Rubin, Dorfman, } \\
\text { a. Dorfman } \\
\text { (10) } \\
(1954)\end{array}$ & $\begin{array}{c}\text { norm. } \\
\text { Cushing } \\
\text { リウマチ熱 }\end{array}$ & 原 & & $\begin{array}{l}\text { hypophysex, } \\
\text { rat AAD 法 }\end{array}$ & $\begin{array}{c}(+) \\
\hat{o}<1 \sim 3.1 \mathrm{mu} / \mathrm{day} \\
+\quad<1 \sim 8.2 \mathrm{mu} / \mathrm{day}\end{array}$ \\
\hline (10) & 藤田 ${ }^{9)}(1957)$ & 正 常人 & $\begin{array}{l}\text { oxycellulose } \\
\text { 吸着 }\end{array}$ & $24 \mathrm{hr}$ 尿 & $\begin{array}{l}\text { hypophysex. } \\
\text { rat AAD 法 }\end{array}$ & $\mathrm{ca} \cdot 0 \cdot 25 \mathrm{mu} / \mathrm{day}$ \\
\hline (11) & $\begin{array}{l}\text { 斉藤(史) })^{35} \text { (1959) }\end{array}$ & $\begin{array}{l}\text { 正常 } \text { 人 } \\
\text { の 他 }\end{array}$ & 藤 田 法 & & & $\begin{array}{l}\text { ca.0.25 1.0mu/day } \\
\text { Addison } \uparrow \text { 喘息 } \uparrow \\
\text { 膠原病 } \uparrow \text { 感染症 } \uparrow \\
\text { Simmonds } \downarrow\end{array}$ \\
\hline (12) & 勝木 ${ }^{17)}$ (1959) & 脳 腫 瘍 & 藤 田 法 & & & $\begin{array}{l}\text { 下垂体腫演, } \\
\text { 大脳腫煬 } \uparrow\end{array}$ \\
\hline (13) & 井 林, 藤 田 & $\begin{array}{l}\text { 正常 } \text { 人 } \\
\text { の }\end{array}$ & $\begin{array}{ll}\text { 安息着 酸 } \\
\text { 吸 }\end{array}$ & $24 \mathrm{hr}$ 尿 & $\begin{array}{l}\text { hypophysex. } \\
\text { rat AAD 法 }\end{array}$ & $\begin{array}{l}\text { norm. ca.0.25 } \\
0.5 \mathrm{mu} / \text { day } \\
\text { Addison } \uparrow \\
\text { Hypopituitarism } \downarrow \\
\text { ステロイド加療患者 } \downarrow\end{array}$ \\
\hline
\end{tabular}

乃至検定法の不備及び少数例のため比較的信頼性が少い. 藤田法に関しては斎藤 ${ }^{35)}$ (1959) の追試によると 正常人 33 例（今 16, ㅇ 17例）の尿中 ACTH は概ね 0.25 1.0mu/day（男子 $0.55 \mathrm{mu}$ ，女子 $0.64 \mathrm{mu）で,}$ Addison 病で中等度の増加, 重症気管支喘息, 中毒性皮膚炎, 慢性関節りウマチ, 痛風, 感染症の各 1 例で 増加が認められると記載されてるる．勝木 ${ }^{17}$ ) (1959) は間脳腫瘍，小脳，橋角腫瘍の各 3 例で正常值，下垂 体腫瘍 2 例中 2 例, 大脳半球腫瘍 5 例中 2 例で増加を指摘した. しかし乍ら本法も吾々自身の再検討によれ ば回収率が不定であり，又正常人でも贋々有意の AAD 值を認めえず，更に今後抽出法に関して検討改良の 余地か残されている様に思われる。 その点今回報告した安息香酸吸着法は操作の簡便さと相俟つて, 回収率 の点で更に改良されたよい方法と信ずる.

ACTH 検定法についても第 6 表の如く徒来種々の方法が考按報告されているが, その特異性, 感度, 精度 等に関して現在最も信頼性の高い屯のはSayers, Sayers, Woodbury ${ }^{32)}$ (1948) の方法とされ, 周知の如く国際 USP 単位の決定にも採用されている ${ }^{10)}$. 本邦においても武田，峰下等 ${ }^{22), 36)}(1955 ， 1958)$ の広汎な検討が

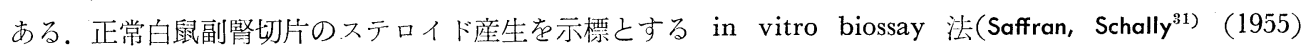

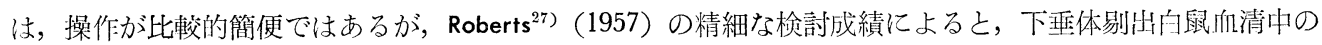


第 6 表 ACTH の検定法

\begin{tabular}{|c|c|c|c|c|}
\hline \multirow{4}{*}{ In vivo } & \multirow[t]{2}{*}{$\begin{array}{l}\text { Ascorbic Acid } \\
\text { による方法 }\end{array}$} & I & A.A.減少法 & $\begin{array}{l}\text { 1. Sayers 原法 (Sayers et al. }{ }^{32} \text { ) 1948) } \\
\text { 2. Munson 変法 (Munson et al. } \text { (M) }^{20} \text { 1948) } \\
\text { 3. Hodges 変法 (Hodges }{ }^{12} \text { ) 1955) } \\
\text { 4. Rerup 変法 }\left(\text { Rerup }^{26} \text { 1958) }\right.\end{array}$ \\
\hline & & II & A.A.放出法 & Munson, Toepel ${ }^{21)}$ (1958) \\
\hline & \multirow{2}{*}{$\begin{array}{l}\text { Steroid } \\
\text { による方法 }\end{array}$} & I & $\begin{array}{l}\text { 下垂体剔出犬 } \\
\text { 副腎静脈血中 } \\
17 \mathrm{OHCS} \text { 法 }\end{array}$ & Nelson, Hume ${ }^{29)}$ (1955) \\
\hline & & $\mathbb{I}$ & $\begin{array}{l}\text { 下垂性剔出白鼠 } \\
\text { 血中 Cortico- } \\
\text {-sterone 法 }\end{array}$ & $\begin{array}{l}\text { Guillemin, Clayton, } \\
\text { Lipscomb }^{11)}(1958)\end{array}$ \\
\hline In vitro & $\begin{array}{l}\text { Steroid } \\
\text { による方法 }\end{array}$ & $\begin{array}{l}\text { I } \\
\text { II }\end{array}$ & $\begin{array}{l}\text { 白鼠副腎切片ス } \\
\text { テロイト産生法 } \\
\text { 副珡皮質腫瘍ス } \\
\text { ライスス法 }\end{array}$ & $\begin{array}{l}\text { Saffran, Schally }{ }^{31)} \text { (1955) } \\
\text { Cohen, Furth }^{6)} \text { (1959) }\end{array}$ \\
\hline
\end{tabular}

ACTH 活性は正常白鼠中のそれと全く差異を示さぬととが指摘され，一般にその特異性の点で本汒は重大 な疑問が残されている現状である。

Nelson，Hume 等 ${ }^{23}$ (1955) の下垂体剔出犬副腎静脈血中 17OHCS 法は方法論的に興味があり，吾々も之 を追試したが，Standard ACTH の検定を含めて 1 匹の下垂体剔出犬で試料 $\mathbf{5}$ 検体程度しか検定が出来ず，

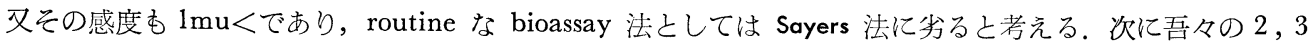
の臨床成績について検討を加えてみたいと思う. 先ず Addison 病に関しては, Sydnor, Sayers 等 ${ }^{34)}$ (1953) は本症 3 例の血中 AGTH を oxycellulose 吸着, AAD 法により定量し, 全例に著明增加 $(2 \sim 4 \mathrm{mu} /$ 血 液 $100 \mathrm{ml}$ ）をみとめ，しかも DOCA，Cortisone 加療後もなお高值を示したと報じた。 Bethune ${ }^{1)}$ (1957) あ 患者冷凍血漿直接注射後の下垂体剔出犬副腎静脈血中 $17 O H C S$ 増加法により $8.4 \pm 7.4 \mathrm{mu} / 100 \mathrm{ml}$ 之同様増加 を指摘した。斎藤 ${ }^{35}$ （1959）は藤田法により本症 2 例の尿中 ACTH の中等度増加をみたと述へているが, 吾々の成績は本症全例に著明増加を認めると共に, 更に興味ある事は Hydrocortisone 加療後正常化の所見 をえたことである，又，hypopituitarism の12例で正常人に比べ有意の減少を認めたが，木症との鑑別診断 上臨床的に重視される Anorexia nervosa 群との間には特に有意の差異は証明出来なかつた。促つて尿中 ACTH 定量は, 従来の GTH, 17OHCS, 17KS 等と同じく両者の鑑別診断的意義は少なく, 既報 ${ }^{14}$ (1959) の如く ACTH 負荷試験, 水負荷試験等が有用之考えられる，次に各種合成皮質ステロイド剤加療患者の iatrogenic adrenal insufficiency については最近漸く臨床的に重視され, 吾々屯最近二, 三の自験成績を中 心にその詳細を紹介した ${ }^{14}$. 吾々の尿中 ACTH 測定成績から iatrogenic adrenal insufficiency の本態は 下垂体 AGTH 合成乃至分泌抑制が一義的であるととを実証するあのである.

Cushing 症候群に関してはその皮質病変の種類と所在について, 術前の鑑別診断が治療予後の点で極めて 重要である. 即ちその病態生理の面から皮質 hyperplasia では血中，尿中の AGTH 増加，逆に腺腫，癌等 ではその減少が想定されている ${ }^{13)}$.

Bornstein $^{4}$ (1950，1952)は hyperplasia による本症 3 例の血中 ACTH の著増を記載したが，同門 Parrot 24)（1955）も同様所見を再び報じた。 その後 Mayo Clinic の Sprague ${ }^{33)}$ (1955) は本症の血中 AGTH を Oxycellulose 吸着, AAD 法 (Sydnor, Sayers 法) で定量, その成績を報告しているが hyperplasia 8 例中 ACTH を証明しえたのは僅か 2 例に止まり，残る 6 例では全く陰性であり，皮質腫煬の 1 例では逆に陽性

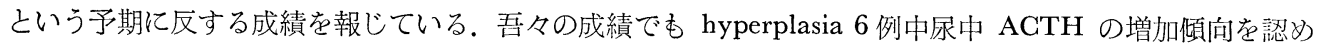
えたのは僅か 2 例にすぎなかつた事は注目される。

なお皮質腺䭪の 1 例では術前 $\mathrm{AAD}$ 值80，-70，-67 (平均-26) で, 術後22，53，-22（平均18)の值を元 
た，副䝳皮質 hyperplasia による Cushing 症候群では，その尿中17KS，17OHCS，17KGS が垡々大きな 日差变動を示し，時に正常值を呈する事は Zimmermann ${ }^{38)}$ (1952), Birke ${ }^{2)}$ 等 (1956) によつて指摘されてい るが尿中 ACTH についても同様の考虑を要する点であろう. 又, hyperplasia による本症発病の初期には ACTH の増加があるが Hydrocortisone 分泌過剩による feed-back 機序のため漸次 AGTH 合成分泌が抑 制されるため ACTH 量の正常化，乃至低下傾向を示すが， hyperplasia 副腎は周知の如く exogene ACTH に hypersensitiv である如く，少量の内因性 ACTH に対しても hypersensitiv であるため皮質からの Hydrocortisone 分泌交進は依然続くものとも理解される.

又, Jailer 等 ${ }^{15}$ ) (1956) が想定した如く hyperplasia 例において分泌立進をみるのは下垂体の所謂 endogene orthodox ACTH ではなく“Corticotropin potentiating factor”である可能性も否定は出来ない.

今後更に検討の俟たれる興味ある重要な課題と考える.

\section{$\mathrm{V}$ 結語}

吾々は安息香酸抽出，下垂体剔出白鼠副腎アスコルビン酸減少法による新らしい尿中 ACTH 定量法を考 按し，その方法の詳細を報告すると共に，2，3 の臨床知見につき述べた. 本法は抽出法の簡便さ, 回収率, 精度等の点で臨床的に極めて有用な方法と信ずる. 正常人（26例）尿中 ACTH (AAD) は平均 $51 \pm 6.5 \mathrm{mg}$

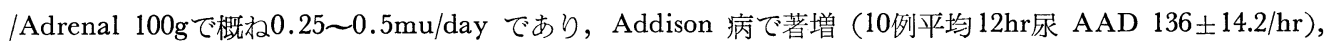

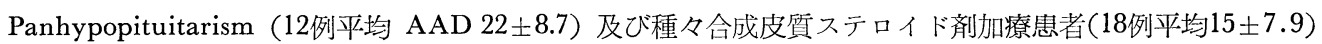

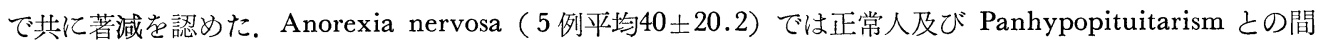
に夫々有意の差は認め難かつた。

Cushing 症候群の皮質腺腫による1例では術前 ACTH の低下を認め術後正常化の傾向を示したが, hyperplasia の 6 例中, 術前 ACTH 増加傾向をみたのは僅か 2 例にすぎなかつた事は興味深く，その点につ き二，三の考察を試みたが，更に今後の検討に俟ちたいと思う。 その他少数例の $2 ， 3$ 内分泌疾患における 測定成績を報告したが，個々の症例について正確な測定值をうるためには更に同一人につき $4 ， 5$ 日間の尿 につき抽出を行ない，かつ 4,5 匹の下垂体剔出白鼠群を用いて検定を試みる事が望ましい.

恩師冲中教授の御指導御校閲を深謝すると共に，U.S.P. Standard ACTH 入手の御便宜を戴いた塩野義 研究所峰下鍿雄博士の御好意に感謝致します。

な打御援助下さつた冲中内科医局の同僚諸氏及び実験助手谷口仲子，西川洋子滖に謝意を表します。

な打本論文要旨は昭和34年11月日本内分泌学会東部部会総会に打いて発表した.

\section{文献}

1) Bethune, J.E., D.H. Nelson, a. G.W. Thorn : J. Glin. Invest. $36: 1701$ (1957). $\quad$ 2) Birke, G. a. E. Diczfalusy : J. Glin. Endocrinol. a. Metabol. $16: 286$ (1956). $\quad 3$ 3) Blumenthal, H.T. : J. Lab. a. Clin. Med. $30: 46$ (1943).

4) Bornstein, J. a. P. Trewhella : Lancet $2: 678$ (1950).

Bornstein, J., C.H. Gray a. D.M.V. Parrot : J. Endocrinol. $8: 40$ (1952). 6) Cohen, A.l. a. J. Furth : Cancer Res. $19: 72$ (1959). $\quad$ 7) Cooke, D.S., E. Graetzer a. M. Reiss : J. Endocrinol. 5 : 89 (1948). 8) De Boissezon, P. : Bull. d'histol. appliq. a. la physiol. $13: 129$ (1936) cited from (19). 藤田拓男 : J. Clin. Endocrinol. a. Metabol. $17: 512$ (1957); 日本内分泌学会雑誌, $33: 334$ (1957). 10) 藤田拓男, 井林博: ホルモンと臨床 $8: 517(1960)$. 11) Guillemin, R., G.W. Clayton a. H.S. Lipscomb: Endocrinol. $63: 349$ (1958). 12) Hodges,J.R. : J. Endocrinol. 12 : 152 (1955). 13) 井 林博, 吉田尚 : 最新医学, $12: 1081$ (1957). 114$)$ 井林博 他 : 日本臨床, $17: 179(1959) ; 18: 591$ (1960). 15) Jailer, J.W., D. Longson a. N.P. Christy : J. Clin. Endocrinol. a. Metabol. $16: 1276$ (1956).

16) Jones, G.E.S. a. N.L.R. Bucher : Endocrinol. $32: 46$ (1943).

17）勝木司馬之 助：第15四日本医学会総会記録 1:731 (1959).

18) Lerner, A.B. a. Y. Takahashi : Personal Com- 
Roberts, S. : Ciba Foundation Colloquia Endocrinol. 11 : 167 (1957).

28) Reiss, M., H. Pegler a. Y.M.L. Golla : Nature $157: 413$ (1946).

29) Roe, J.H. a. C.A. Kuether: J. Biol. Chem. $147: 399$ (1943) ; $152: 511$ (1944).

30) Rubin, B.L., R.I. Dorfman a. A. Dorfman : J. Clin. Endocrinol. a. Metabol. $14: 154$ (1954). 